\title{
Correction to: Standard and Non-standard Suppositions and Presuppositions
}

\section{Maja Kasjanowicz ${ }^{1}$}

Published online: 21 May 2021

(c) Springer Nature B.V. 2021

\section{Correction to: Axiomathes https://doi.org/10.1007/s10516-021-09535-w}

In the original publication, The Acknowledgement section was incomplete. The correction version should read as below.

Acknowledgements The preparation of this work was supported by the National Science Centre, Poland, through research grant No. 2015/19/B/HS1/03306. I would like to thank professor Maciej Witek for many productive and helpful consultation. I would also like to express my gratitude to the anonymous reviewer, whose remarks and comments helped me improve the manuscript.

Publisher's Note Springer Nature remains neutral with regard to jurisdictional claims in published maps and institutional affiliations.

The original article can be found online at https://doi.org/10.1007/s10516-021-09535-w.

Maja Kasjanowicz

majka.kasjanowicz@gmail.com

1 Institute of Philosophy and Cognitive Science, University of Szczecin, Aleja Papieża Jana Pawła II 22A, 70-453 Szczecin, Poland 